\title{
Progress on bringing together raptor collections in Europe for contaminant research and monitoring in relation to chemicals regulation
}

\author{
Paola Movalli ${ }^{1}$ (D) Guy Duke ${ }^{2} \cdot$ Gloria Ramello $^{3} \cdot$ René Dekker $^{1} \cdot$ Al Vrezec $^{4} \cdot$ Richard F. Shore $^{5} \cdot$ \\ Antonio García-Fernández ${ }^{6} \cdot$ Chris Wernham $^{7}$ • Oliver Krone ${ }^{8} \cdot$ Nikiforos Alygizakis $^{9} \cdot$ Alexander Badry $^{10}$. \\ Fausto Barbagli ${ }^{11}$. Koos Biesmeijer ${ }^{1}$. Giovanni Boano ${ }^{4}$. Alexander L. Bond ${ }^{12} \cdot$ Yael Choresh $^{13}$. \\ Jan Bolding Christensen ${ }^{14} \cdot$ Alessandra Cincinelli ${ }^{15} \cdot$ Sara Danielsson $^{16} \cdot$ Andreia Dias $^{17} \cdot$ Rune Dietz $^{18}$. \\ Marcel Eens ${ }^{19}$ - Silvia Espín ${ }^{6}$. Igor Eulaers ${ }^{18}$. Sylke Frahnert ${ }^{20}$ - Tibor I. Fuiz ${ }^{21}$ - Georgios Gkotsis ${ }^{22}$. \\ Natalia Glowacka ${ }^{9}$ - Pilar Gómez-Ramírez ${ }^{6}$ - Marco Grotti ${ }^{23}$ - Michel Guiraud ${ }^{24}$ • Peter Hosner ${ }^{25}$ • Ulf Johansson ${ }^{16}$. \\ Veerle L.B. Jaspers ${ }^{26}$. Pepijn Kamminga ${ }^{1}$ • Jan Koschorreck ${ }^{10}$ • Burkhard Knopf ${ }^{27}$ • Eero Kubin ${ }^{28}$ • Sabrina LoBrutto ${ }^{29}$. \\ Rui Lourenco ${ }^{30}$ - Tania Martellini ${ }^{15}$ - Emma Martínez-López ${ }^{6}$. Rafael Mateo ${ }^{31}$ - Maria-Christina Nika ${ }^{22}$. \\ Varvara Nikolopoulou ${ }^{22}$. Dan Osborn ${ }^{32}$ • Olivier Pauwels ${ }^{33}$ - Marco Pavia ${ }^{34}$ • M. Glória Pereira ${ }^{5}$ Heinz Rüdel $^{35}$. \\ Pablo Sanchez-Virosta ${ }^{6}$. Jaroslav Slobodnik ${ }^{9} \cdot$ Christian Sonne $^{18} \cdot$ Nikolaos Thomaidis $^{22} \cdot$ Till Töpfer $^{36}$. \\ Gabriele Treu $^{10} \cdot$ Risto Väinölä ${ }^{37} \cdot$ Jari Valkama $^{37}$. Steven van der Mije ${ }^{1}$ - Didier Vangeluwe ${ }^{33} \cdot$ Ben H. Warren $^{24}$. \\ Friederike Woog $^{38}$
}

Received: 18 April 2019 / Revised: 18 April 2019 / Accepted: 30 April 2019 / Published online: 27 May 2019

(C) Springer-Verlag GmbH Germany, part of Springer Nature 2019

Environmental contaminants impose multi-billion Euro costs on human and wildlife health in Europe (Trasande et al. 2015). Although there are more than 60,000 chemicals marketed in Europe, so far, only 600 chemicals have been screened and identified as PBT (persistent, bioaccumulative, toxic), ED (endocrine disrupting) and/or CMR (carcinogenic, mutagenic, toxic for reproduction) (Gkotsis et al. 2019). A suite of EU chemicals legislation (EC 2001, EC 2004a, EC 2004b, EC 2004c, EC 2006, EC 2008, EC 2009a, EC 2009b, EU 2012) aims to reduce chemical risks to humans and wildlife, and the EU's Seventh Environment Action Programme (EU 2014) calls for better scientific knowledge towards achieving a nontoxic environment.

Movalli et al. (2017) noted the value of raptors as sentinels of environmental health in general, and highlighted in particular the potential value of raptor tissue collections, which can be analysed for contaminant exposure to inform risk assessment of chemicals, assess the effectiveness of

Responsible editor: Philippe Garrigues

Paola Movalli

paola.movalli@naturalis.nl

Extended author information available on the last page of the article chemicals risk management measures and provide early warning of emerging contaminant problems. They argued for development of a framework bringing together raptor tissue collections in Europe-including those of natural history museums (NHMs), environmental specimen banks (ESBs) and others (e.g. in research institutions) - in support of contaminant research and monitoring for better chemicals management. They suggested this framework would involve among other things identifying and digitising relevant collections and developing a searchable database of these collections to make them more visible and accessible to ecotoxicologists and competent authorities.

Here, we outline progress that has been made in this regard through the launch of two mutually reinforcing initiatives, the COST Action European Raptor Biomonitoring Facility (ERBFacility ${ }^{1}$ ), which was launched in October 2017 and in which 27 COST member countries are participating, and the EU LIFE project Systematic use of contaminant data from apex predators and their prey in chemicals management (LIFE $\mathrm{APEX}^{2}$ ), which was launched in September 2018.

\footnotetext{
${ }^{1}$ www.erbfacility.eu

2 www.lifeapex.eu
} 
Using raptors as particularly appropriate sentinels for PBT compounds (Movalli et al. 2018), ERBFacility will help answer what the environmental risks are for specific chemicals, whether there are emerging contaminant problems needing remedial action and whether legislation is at all effective in reducing environmental exposure to contaminants in Europe. ERBFacility builds on 10 years of work involving ecotoxicologists and ornithologists leading up to and under the European Science Foundation's research networking programme EURAPMON (Research and Monitoring for and with Raptors in Europe) (see, for example, Movalli et al. 2008, Gómez-Ramírez et al. 2014, Espín et al. 2016, Derlink et al. 2018, Duke et al. 2018). ${ }^{3}$

At its first General Meeting in Ciudad Real, Spain, in February 2018, ERBFacility set in motion work to bring together NHMs, ESBs and other research collections towards development of a European Raptor Specimen Bank (ERSpeB). ERBFacility has since concluded a review of raptor collections in Europe (Ramello et al. n.d.). The review, which collated data from over a hundred collections across Europe, revealed that many thousands of raptor specimens arrive annually at these collections, offering a very substantial resource of raptor tissue samples for contaminant monitoring. In the UK, specimens are processed and tissues stored by the Predatory Bird Monitoring Scheme maintained by the Centre for Ecology and Hydrology (Walker et al. 2008). In Sweden, the lead is taken by the national ESB at the Naturhistorika Rijkmuseet. A number of research collections also exist around Europe, such as that of the Leibniz-Institute for Zoo and Wildlife Research, Germany. However, such specimen banks and research collections, set up specifically for the purposes of contaminant monitoring, are the exception rather than the rule. In most countries, the main recipients of raptor specimens are NHMs. Indeed, the review found that around $75 \%$ of responding NHMs across Europe receive fresh raptor/owl specimens. Most NHMs freeze raptor carcasses on arrival and then process and freeze wet tissues; indeed, around a third of responding NHMs are already active in storing frozen raptor tissue samples suitable for contaminant monitoring

At a recent ERBFacility meeting convened at the Royal Belgian Institute of Natural Sciences in Brussels, collections came together to validate the review of raptor collections and consider how to build on this towards development of the European Raptor Specimen Bank. The meeting found that there is strong interest among collections to work together in this regard. However, many collections, particularly in eastern and southern Europe, are stretched for resources, so any new 'ask' (e.g. in terms of expanding tissue collections and/or strengthening standard operating procedures to ensure sample quality) must be tightly specified. Moreover, collections cannot be expected to build a

\footnotetext{
${ }^{3}$ www.eurapmon.eu
}

substantial raptor tissue bank unless there is a clear regulatory demand for contaminant data and resources for the necessary analyses to be performed.

There exists here something of a Catch 22, in that regulatory demand is likely to grow only once the ability of raptor biomonitoring to provide pan-European assessments pertinent to chemicals management is proven, while proving this ability requires a substantial sample bank to be available in the first place. Overcoming this will probably involve carefully targeted proof of concept work on one or two selected species and tissue matrices for which a substantial pan-European bank of samples already exists, and for one or two priority substances of particular interest to regulators.

There are clear incentives for collections to engage in this work. These include: the opportunity to engage in a major European initiative with key regulatory applications, helping to demonstrate the societal relevance of collections; the opportunity presented by novel collaboration between NHMs, ESBs and research collections; the opportunity to expand research interests into ecotoxicology, and to expand publications output; and the opportunity to know of and exchange samples with other NHMs and thereby broaden individual collections.

Taking forward the concept of a distributed ERSpeB will involve further work under the auspices of the COST Action on a number of issues, building on relevant existing networks such as the Consortium of European Taxonomic Facilities and the network of European Bird Curators. These include: prioritising species, tissue matrices and compounds and carrying out proof of concept work; addressing legal, personnel and freezer constraints to expanding raptor tissue sample collections and shipping samples for analysis; adapting NHM standards and protocols (learning from ESBs) for the gathering, processing and storage of samples, to enhance sample quality for contaminant analysis; developing appropriate policy on access to samples to ensure valuable samples required for contaminant monitoring are not consumed for other purposes; and circumscribing the data content of the European samples database and how it will be developed, populated and updated to provide real-time information on raptor tissue samples across Europe. These issues will all be addressed by a sequence of scientific missions and meetings planned by ERBFacility for the next 12-15 months.

This paper focuses on work being done in the 'collections arena' under the auspices of ERBFacility, but it is worth noting that ERBFacility also involves work in the 'analytical arena', involving ecotoxicologists, veterinary scientists and chemists, to develop a prioritised European Raptor Biomonitoring Scheme (ERBiomS), and work in the 'field arena' involving field ornithologists and ecologists to develop a European Raptor Sampling Programme (ERSamP). Advancing work towards a comprehensive European Raptor Biomonitoring Facility, capable of delivering pan-European 
contaminant data for chemicals management, involves collaboration across these three arenas.

While this work is progressing under ERBFacility, LIFE APEX is working to demonstrate the systematic use of contaminant data from raptors and other apex predators for chemicals management. Like ERBFacility, LIFE APEX is building collaborations between collections and analytical laboratories. But while the focus of ERBFacility is on building networks across the collections, analysis and field arenas and developing the overall Facility, the focus of LIFE APEX is on demonstrating that contaminant data from apex predators has useful regulatory applications, notably in relation to the REACH and Biocides regulations (Alygizakis et al. 2019; Gkotsis et al. 2019; Koschorreck et al. 2019).

LIFE APEX will in particular demonstrate the use of widescope target screening (of more than 2400 contaminants of emerging concern-CECs), wide-scope suspect screening (of more than 40,000 CECs) and non-target screening of samples from raptors (in the terrestrial environment) and other apex predators (in the freshwater and marine environments) to help the European Chemicals Agency (ECHA) prioritise substances (among the many tens of thousands currently used) for more strenuous PBT assessments and identify predominant chemical mixtures in biota. LIFE APEX will also demonstrate the power of targeted analyses of raptor matrices to assess the effectiveness of EU chemicals risk management measures. Proof of concept work on this latter demonstrator is under way by the Naturalis Biodiversity Center with the UK Centre for Ecology and Hydrology (which hosts the UK Predatory Bird Monitoring Scheme)

Taken together, the growing collaborations across the collections, analysis and field arenas under ERBFacility and LIFE APEX offer considerable promise to enhance early warning of emerging contaminant problems, for more timely identification and management of persistent and bioaccumulative substances in the environment, for putting risk management measures in place more quickly, for better understanding predominant chemical mixtures in the environment, and to ascertain whether risk management measures (and by extension chemicals regulations) are actually delivering on their purpose in reducing negative impacts on human and wildlife health. This will complement ongoing work to monitoring impacts of contaminants on human health. ${ }^{4}$

Funding information European Raptor Biomonitoring Facility COST Action (CA16224) is supported by COST (European Cooperation in Science and Technology) and funded by the Horizon 2020 Framework Programme of the European Union.

Life APEX is financed by the European Union through the program LIFE17 ENV/SK/000355 'Systematic use of contaminant data from apex predators and their prey in chemicals management'.

\footnotetext{
$\overline{{ }^{4} \text { www.hbm4eu.eu }}$
}

\section{References}

Alygizakis N, Cincinelli A, Dekker R, Gkotsis G, Duke G, Glowacka N, Knopf B, Koschorreck J, Martellini T, Movalli P, Nika MC, Nikolopoulou V, Rüdel H, Shore R, Thomaidis N, Treu G, Slobodnik J (2019) Determination of emerging substances in top predators and their prey using state-of-the-art chemical monitoring methods. 5th International Conference on Environmental Specimen Banks, Stockholm 3-5 June 2019

Derlink M, Wernham C, Bertoncelj I, Kovacs A, Saurola P, Duke G, Movalli P, Vrezec A (2018) A review of raptor and owl monitoring activity across Europe: its implications for capacity building towards pan-European monitoring. Bird Study 65:S4-S20. https://doi.org/ 10.1080/00063657.2018.1447546

Duke G, Vrezec A, Movalli P, Bertoncelj I, Wernham C (2018) Editorial. Bird Study 65:S1-S2. https://doi.org/10.1080/00063657.2018. 1552919

EC (2001) Directive 2001/83/EC of the European Parliament and of the Council of 6 November 2001 on the Community code relating to medicinal products for human use

EC (2004a) Directive 2004/28/EC of the European Parliament and of the Council of 31 March 2004 amending Directive 2001/82/EC on the Community code relating to veterinary medicinal products

EC (2004b) Regulation (EC) no 726/2004 of the European Parliament and of the Council of 31 March 2004 laying down community procedures for the authorisation and supervision of medicinal products for human and veterinary use and establishing a European Medicines Agency

EC (2004) Directive 2004/35/CE of the European Parliament and of the Council of 21 April 2004 on environmental liability with regard to the prevention and remedying of environmental damage

EC (2006) Regulation (EC) No 1907/2006 of the European Parliament and of the Council of 18 December 2006 concerning the Registration, Evaluation, Authorisation and Restriction of Chemicals (REACH)

EC (2008) Directive 2008/56/EC of the European Parliament and of the Council of 17 June 2008 establishing a framework for community action in the field of marine environmental policy (Marine Strategy Framework Directive)

EC (2009) Regulation (EC) No 1107/2009 of the European Parliament and of the Council of 21 October 2009 concerning the placing of plant protection products on the market

EC (2009) Regulation (EC) No 1069/2009 of the European Parliament and of the Council of 21 October 2009 laying down health rules as regards animal byproducts and derived products not intended for human consumption

Espín S, Garcia-Fernandez AJ, Herzke D, Shore RF, van Hattum B, Martinez-Lopez E, Coeurdasser M, Eulaers I, Fritsch C, GomezRamirez P, Jaspers VLB, Krone O, Duke G, Helander B, Mateo R, Movalli P, Sonne C, Van den Brink NW (2016) Tracking pancontinental trends in environmental contamination using sentinel raptors - what types of samples should we use? Ecotoxicol 25(4), $777-801$

EU (2012) Regulation (EU) No 528/2012 of the European Parliament and of the Council of 22 May 2012 concerning the making available on the market and use of biocidal products

EU (2014) General Union Environment Action Programme to 2020. Living well, within the limits of our planet. Luxembourg: Publications Office of the European Union. https://doi.org/10. 2779/66315

Gkotsis G, Alygizakis N, Cincinelli A, Dekker R, Duke G, Glowacka N, Knopf B, Koschorreck J, Martellini T, Movalli P, Nika MC, Nikolopoulou V, Ruedel H, Shore R, Thomaidis NS, Treu G. Slobodnik J (2019) Determination of emerging contaminants in apex predators and their prey from European Specimen Banks and 
Natural History Museums by High Resolution Mass Spectrometry Techniques. 17th International Conference on Chemistry and the Environment, which will be held in Thessaloniki, 16-20 June 2019

Gómez-Ramírez P, Shore RF, Van Den Brink NW, Van Hattum B, Bustnes JO, Duke G, Fritsch C, García-Fernández AJ, Helander BO, Jaspers V, Krone O, Martínez-López E, Mateo R, Movalli P, Sonne C (2014) An overview of existing raptor contaminant monitoring activities in Europe. Environ Internat 67:12-21

Koschorreck J, Alygizakis N, Cincinelli A, Dekker R, Duke G, Glowacka N, Knopf B, Martellini T, Movalli P, Nika MC, Ruedel H, Shore R, Thomaidis NS, Treu G. Slobodnik J (2019) LIFE APEX - systematic use of contaminant data from apex predators and their prey in chemicals management. SETAC Europe 29th Annual Meeting in Helsinki, Finland (26-30 May, 2019)

Movalli P, Duke G, Osborn D (2008) Introduction to monitoring for and with raptors. Ambio 37(6):395-397

Movalli P, Dekker R, Koschorreck J, Treu G (2017) Bringing together raptor collections in Europe for contaminant research and monitoring in relation to chemicals regulations. Environ Sci Pollut Res 24: 24057-24060. https://doi.org/10.1007/s11356-017-0096-s
Movalli P, Krone O, Osborn D, Pain D (2018) Monitoring contaminants, emerging diseases and environmental change with raptors and links to human health. Bird Study 64(sup1):596-5109

Ramello G, Dekker R, Duke G, van der Mije S, Movalli P (n.d.) A review of European Raptor Tissue Collections

Trasande L, Zoeller RT, Hass U, Kortenkamp A, Grandjean P, Myers JP, DiGangi J, Bellanger M, Hauser R, Legler J, Skakkebaek NE, Heindel J (2015) Estimating burden and disease costs of exposure to endocrine-disrupting chemicals in Europe. J Clin Endocrinol Metab 100(4):1245-1255

Walker LA, Shore RF, Turk A, Pereira MG, Best J (2008) The predatory bird monitoring scheme (PBMS) - identifying chemical risks to top predators in Britain. Ambio 37:466-471

Publisher's note Springer Nature remains neutral with regard to jurisdictional claims in published maps and institutional affiliations.

\section{Affiliations}

Paola Movalli ${ }^{1} \mathbb{D} \cdot$ Guy Duke $^{2} \cdot$ Gloria Ramello $^{3} \cdot$ René Dekker $^{1} \cdot$ Al Vrezec $^{4} \cdot$ Richard F. Shore $^{5}$. Antonio García-Fernández ${ }^{6} \cdot$ Chris Wernham $^{7}$. Oliver Krone ${ }^{8} \cdot$ Nikiforos Alygizakis $^{9}$ • Alexander Badry ${ }^{10}$. Fausto Barbagli ${ }^{11} \cdot$ Koos Biesmeijer ${ }^{1}$. Giovanni Boano ${ }^{4}$. Alexander L. Bond ${ }^{12} \cdot$ Yael Choresh $^{13}$. Jan Bolding Christensen ${ }^{14}$. Alessandra Cincinelli ${ }^{15}$. Sara Danielsson ${ }^{16}$. Andreia Dias ${ }^{17} \cdot$ Rune Dietz $^{18} \cdot$ Marcel Eens $^{19}$. Silvia Espín ${ }^{6}$ • Igor Eulaers ${ }^{18}$. Sylke Frahnert ${ }^{20}$. Tibor I. Fuiz ${ }^{21}$. Georgios Gkotsis ${ }^{22}$ • Natalia Glowacka ${ }^{9}$.

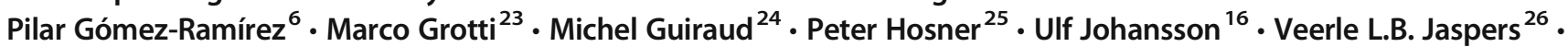
Pepijn Kamminga ${ }^{1}$ - Jan Koschorreck ${ }^{10}$ - Burkhard Knopf ${ }^{27}$ - Eero Kubin ${ }^{28}$ - Sabrina LoBrutto ${ }^{29}$. Rui Lourenco ${ }^{30}$. Tania Martellini ${ }^{15}$ - Emma Martínez-López ${ }^{6}$. Rafael Mateo ${ }^{31}$ - Maria-Christina Nika ${ }^{22}$ - Varvara Nikolopoulou ${ }^{22}$. Dan Osborn ${ }^{32}$. Olivier Pauwels ${ }^{33}$. Marco Pavia ${ }^{34}$ - M. Glória Pereira ${ }^{5}$. Heinz Rüdel ${ }^{35}$ • Pablo Sanchez-Virosta ${ }^{6}$. Jaroslav Slobodnik ${ }^{9} \cdot$ Christian Sonne $^{18} \cdot$ Nikolaos Thomaidis $^{22} \cdot$ Till Töpfer $^{36} \cdot$ Gabriele Treu $^{10} \cdot$ Risto Väinölä $^{37}$. Jari Valkama ${ }^{37}$ - Steven van der Mije ${ }^{1}$ - Didier Vangeluwe ${ }^{33} \cdot$ Ben H. Warren ${ }^{24}$ - Friederike Woog ${ }^{38}$

1 Naturalis Biodiversity Center, Vondelaan 55, 2332 AA Leiden, Netherlands

2 Environmental Change Institute, University of Oxford, 3 South Parks Road, Oxford OX1 3QY, UK

3 Museo Civico di Storia Naturale di Carmagnola, Via S Francesco di Sales, 188, 10022, Carmagnola, Torino, Italy

4 National Institute for Biology, Večna pot 111, 1000 Ljubljana, Slovenia

5 Centre for Ecology \& Hydrology, Lancaster Environmental Centre, Lancaster LA1 4AP, UK

6 Area of Toxicology, Department of Health Sciences, University of Murcia, Campus de Espinardo, 30100 Murcia, Spain

7 BTO Scotland, Beta Centre (Unit 15), Stirling University Innovation Park, Stirling FK9 4NF, UK

8 Department of Wildlife Diseases, Leibniz Institute for Zoo and Wildlife Research, Alfred-Kowalke-Strasse 17, 10315 Berlin, Germany
9 Environmental Institute, Okružná 784/42, 97241 Koš, Slovak Republic

10 German Environment Agency, 06844 Dessau, Germany

11 Museo di Storia Naturale dell'Università di Firenze, Sezione di Zoologia "La Specola", Via Romana 17, 50125 Florence, Italy

12 Department of Life Sciences, Natural History Museum, Akeman Street, Tring, Hertfordshire HP23 6AP, UK

13 Shamir Research Institute, University of Haifa, 199 Aba Chushi Ave., Haifa, Israel

14 Natural History Museum of Denmark, Universitetsparken 15, 2100 Copenhagen Ø, Denmark

15 University of Florence, 50019 Sesto Fiorentino, Italy

16 Naturhistoriska riksmuseet, Box 50007, 10405 Stockholm, Sweden

17 CIBIO-InBIO, Universidade de Évora, Casa Cordovil $2^{\mathrm{a}}$ Andar, Rua Dr. Joaquim Henrique da Fonseca, 7000-890 Évora, Portugal

18 Aarhus University, Frederiksborgvej 399, 4000 Roskilde, Denmark 
19 Department Biology, University of Antwerp, Universiteitsplein 1, Wilrijk, Antwerp, Belgium

20 Museum für Naturkunde, Leibniz-Institut für Evolutions- und Biodiversitätsforschung, Invalidenstraße 43,

10115 Berlin, Germany

21 Hungarian Natural History Museum, Baross u 13, Budapest, Hungary

22 National and Kapodistrian University of Athens, 15771 Athens, Greece

23 Department of Chemistry and Industrial Chemistry, University of Genoa, Via Dodecaneso 31, Genoa, Italy

24 Institut de Systématique, Evolution, Biodiversité (ISYEB), Muséum National d'Histoire Naturelle, CNRS, Sorbonne Université, EPHE, UA, CP 51, 57 Rue Cuvier, 75005 Paris, France Danish Museum of Natural History, University of Copenhagen, Øster Voldgade 5-7, 1350 København K, Denmark

26 Norwegian University of Science and Technology, Høgskoleringen 5, Trondheim, Norway

27 Fraunhofer Institute for Molecular Biology and Applied Ecology, 57392 Schmallenberg, Germany

28 Oulu University, Paavo Havaksen tie 3, Oulu, Finland
29 Dept. STEBICEF, Section Animal Biology, University of Palermo, via Archirafi 18, 90123 Palermo, Italy

30 Laboratório de Ornitologia, Instituto de Ciências Agrárias e Ambientais Mediterrânicas ICAAM, Universidade de Évora, Pólo da Mitra, Valverde, Évora, Portugal

31 Institute for Game and Wildlife Research, Ronda de Toledo 12, Ciudad Real, Spain

32 Department of Earth Sciences, University College London, Gower Street, London WC1E 6BT, UK

33 Institut Royal des Sciences Naturelles de Belgique, Rue Vautier 29, B-1000 Brussels, Belgium

34 Museo di Geologia e Paleontologia, Dipartimento di Scienze della Terra, Via Valperga Caluso 35, I-10125 Torino, Italy

35 Fraunhofer Institute for Molecular Biology and Applied Ecology, 57392 Schmallenberg, Germany

36 Zoological Research Museum Alexander Koenig, Adenauerallee 160, 53113 Bonn, Germany

37 Finnish Museum of Natural History, University of Helsinki, Post Box 17, FI-00014 Helsinki, Finland

38 Staatliches Museum für Naturkunde Stuttgart, Rosenstein 1, Stuttgart, Germany 